\title{
EDITORIAL
}

\section{SOBRE O CURRÍCULO MÍNIMO DO CURSO DE MEDICINA VETERINÁRIA}

As Instituições de Ensino de Medicina Veterinária devem buscar o autoconhecimento dos cursos, mas não devem se ater somente às variáveis internas que interferem nas atividades acadêmicas. Devem também buscar uma adequação ao que podemos chamar de "eficácia externa", ou seja, adequação entre os profissionais que a Universidade forma e as exigências da sociedade na qual eles irão atuar. cursos.

É preciso refletir sobre algumas ações que levam à melhoria da qualidade dos

Urge buscar o perfil do médico veterinário que estará atuando no início do próximo século. Acredito que o nosso aluno, fruto da sociedade, esteja nos alertando a cada dia sobre a postura que devemos adotar na sua formação acadêmica. Fundamental é desestimularmos os currículos extensos. O arcabouço mínimo tem que ser atingido, mas o complemento deve ser decisão do acadêmico. Para isto as Instituições devem se preparar ampliando o repertório de disciplinas optativas. Assim, é de se esperar que o aluno tenha mais tempo para as atividades de estudo em bibliotecas e maior dedicação aos projetos de extensão e de pesquisa em andamento.

Com esse perfil de acadêmico estaremos institucionalizando um processo de renovação continuado de nosso currículo, definido para cada acadêmico, e de acordo com suas aspirações profissionais.

Além da interação das atividades de ensino, pesquisa e extensão, não podemos mais fechar os olhos à precária integração entre o ciclo básico e o profissional, onde a distância física, na maioria das Escolas, não parece ser a única dificuldade encontrada. Os professores do ciclo básico encontram-se alheios ao contexto do que é feito nas Escolas de Veterinária, enquanto os professores das disciplinas vinculadas ao ciclo profissional desconhecem o que se faz naqueles Institutos.

A sobrecarga horária obrigatória impede que o aluno, mais uma vez, seja o responsável pela integração entre o ciclo básico e o ciclo profissional, pois ao vivenciar as duas realidades saberá sanar, se lhe dermos oportunidade, esse entrave, associando a oportunidade e os benefícios ao interesse e à demanda.

Portanto, redimensionar os créditos obrigatórios e ampliar os optativos é decisão urgente para corrigir entraves que vêm se perpetuando, e para torná-los compatíveis com a educação médico veterinária que as demandas sociais estão a nos exigir.

Ricardo Junqueira Del Carlo Professor Titular de Cirurgia Diretor da Faculdade de Veterinária Universidade Federal de Viçosa 